\title{
FAKTOR-FAKTOR YANG MEMPENGARUHI KEPUASAN NASABAH DAN DAMPAKNYA PADA LOYALITAS NASABAH PT.BRI SIMPANG ENAM RANTAUPRAPAT
}

\author{
Pristiyono \\ Dosen Tetap Sekolah Tinggi Ilmu Ekonomi (STIE) Labuhanbatu
}

\begin{abstract}
ABSTRAK
Penelitian ini bertujuan untuk mengetahui pengaruh langsung pelayanan terhadap kepuasan nasabah, untuk mengetahui pengaruh langsung produk terhadap kepuasan nasabah, untuk mengetahui pengaruh langsung citra terhadap kepuasan nasabah, untuk mengetahui pengaruh langsung teknologi terhadap kepuasan nasabah, untuk mengetahui pengaruh langsung lokasi terhadap kepuasan nasabah dan untuk mengetahui pengaruh langsung kepuasan terhadap loyalitas nasabah. Pada penelitian ini menggunakan metode deskriptif dan analisis kuantitatif. Selanjutnya data yang digunakan adalah data primer dan data sekunder. Penelitian ini diawali dengan mengumpulkan data sekunder yaitu dengan melakukan studi literatur yang mencakup kajian teori, penelitian sebelumnya dan model yang berkaitan dengan masalah yang diperoleh dari perpustakaan dan internet. Kemudian dilanjutkan dengan pengumpulan data primer melalui kuesioner dari 100 (seratus) responden yang merupakan nasabah Bank Rakyat Indonesia Simpang Enam Rantauprapat. Teknik pengambilan sampel yang digunakan dalam penelitian ini adalah metode purposive sampling. Teknik analisis data yang digunakan analisis jalur (path analysis) dengan AMOS. Hasil penelitian menunjukkan bahwa variabel pelayanan tidak berpengaruh langsung terhadap kepuasan, variabel produk berpengaruh langsung terhadap kepuasan, variabel citra berpengaruh langsung terhadap kepuasan, variabel teknologi berpengaruh langsung terhadap kepuasan, variabel lokasi berpengaruh langsung terhadap kepuasan dan variabel kepuasan berpengaruh langsung terhadap loyalitas.
\end{abstract}

Kata Kunci : Pelayanan, Produk, Citra, Teknologi, Lokasi, Kepuasan dan Loyalitas. 


\section{Pendahuluan}

Berbagai strategi pemasaran yang efektif dan efisien banyak dilakukan perusahaan bertujuan bukan hanya untuk tetap bertahan hidup dalam menghadapi persaingan yang semakin ketat dengan perusahaan-perusahaan lainnya melainkan untuk dapat memenangkan persaingan tersebut. Bentuk strategi yang ditempuh perusahaan perbankan untuk menjadi leader dalam persaingan semata juga tidak hanya meningkatkan profitabilitasnya tetapi bagaimana meningkatkan kepuasan kepada nasabah serta memelihara tingkat loyalitas nasabah. Dalam abad 21 ini perusahaan perbankan tidak boleh menganggap sepele tentang kepuasan nasabah apalagi loyalitas nasabah, hal ini dikarenakan kepuasan nasabah erat kaitannya dengan loyalitas nasabah di masa mendatang. Secara teori hubungan kepuasan dengan loyalitas membuktikan kedua variabel tersebut merupakan faktor yang senantiasa harus diperhatikan oleh perusahaan perbankan.

Perusahaan perbankan di masa depan akan terus bergerilya dalam pemasarannya untuk merebut hati nasabah. Masyarakat sebagai pengguna jasa kini semakin selektif dalam memilih bank untuk menitipkan dana yang dimiliki untuk menghindari risiko kehilangan dana akibat buruknya kinerja suatu bank. Dalam hal ini unsur penting untuk memelihara kepuasan nasabah menurut Noor (2011) hasil penelitiannya menunjukkan bahwa tingkat faktor kecepatan pelayanan, jenis produk yang ditawarkan, citra perusahaan, teknologi perbankan dan lokasi bank secara bersamaan terbukti berpengaruh terhadap kepuasan pelanggan pada PT Cabang Rakyat Bank Indonesia Pangkalan Bun. Secara umum perusahaan perbankan dalam kegiatan bisnisnya mengutamakan unsur pelayanan. Pelayanan merupakan salah satu faktor mendukung terciptanya kepuasan nasabah. Tindakan pelayanan yang berdasarkan sistem, prosedur, dan metode sesuai ketentuan perusahaan merupakan langkah tepat dalam rangka memenuhi kebutuhan nasabah sesuai dengan haknya akan memungkinkan nasabah memperkuat loyalitas sehingga faktor pelayanan yang baik menjadi penting dalam keberhasilan operasional perusahaan.

Unsur produk perbankan biasanya dapat mempengaruhi tingkat kepuasaan nasabah. Produk yang sesuai dengan nasabah dapat dinilai dari konsistensinya nasabah tetap menggunakan produk perusahaan dalam jangka waktu tertentu seperti melakukan transaksi menyetor uang, melakukan kliring dan bahkan melanjutkan kerja sama dalam pinjaman. Jika hal tersebut masih terjadi pada saat ini maka hal ini menandakan terdapat kepuasan yang dirasakan nasabah sehingga menciptakan kelekatan emosional terhadap produk tersebut. Maka dari itu, perusahaan harus mampu memberikan kepuasan melalui penampilan produk yang lebih spesifik dan mempunyai karakteristik tersendiri yang mampu memuaskan nasabah.

Faktor lain yang mempengaruhi kepuasan adalah citra. Citra perusahaan dapat dirasakan oleh nasabah setelah terjadi transaksi atas produk atau layanan yang ditawarkan perusahaan perbankan. Citra yang positif akan membantu nasabah untuk memilih produk atau layanan yang ditawarkan perusahaan perbankan. Citra merupakan unsur terpenting dalam perkembangan perusahaan tersebut ke depan dalam menghadapi tingginya persaingan, karena citra merupakan sebuah jembatan yang menghubungkan antara perusahaan dalam suatu industri dengan nasabah sebagai pengguna industri tersebut. Sebagian perusahaan juga menganggap bahwa citra perusahaan dapat menumbuhkan loyalitas nasabah yang akan mendatangkan keuntungan jangka panjang bagi perusahaan

Dalam perusahaan perbankan penggunaan fasilitas teknologi tentunya akan memudahkan dalam proses pelayanan, perusahaan semakin dituntut untuk meningkatkan pelayanan kepada nasabah dengan menyediakan fasilitas-fasilitas supaya tidak kalah bersaing. Faktor teknologi bagi perusahaan perbankan pada saat ini dapat digambarkan sebagai jantung operasionalnya perbankan, Perusahaan perbankan menerapkan teknologi untuk memberikan 
kemudahan kepada nasabah untuk menikmati seluruh pelayanan yang ditawarkan perusahaan perbankan. Teknologi perbankan harus mampu mensinergikannya dengan kebutuhan dengan permintaan nasabah atas jasa perusahaan perbankan sebagai bagian strategi bisnis dalam skala luas. Dengan adanya inovasi pada teknologi sebagai cara perusahaan untuk memudahkan nasabah dapat mengakses layanan-layanan secara online. Hal inilah yang mendasari begitu pentingnya peranan teknologi bagi industri perbankan.

Untuk menjalankan kegiatan perusahaan tersebut diperlukan suatu tempat usaha yang dikenal dengan lokasi, baik sebagai tempat menjalankan aktivitas yang melayani nasabah, aktivitas produksi, aktivitas penyimpanan, ataupun untuk mengendalikan kegiatan perusahaan secara menyeluruh. Lokasi strategis dan baik serta tersedianya akses cepat dan dapat menarik nasabah lainnya dan memberikan kepuasan nasabah. Oleh karena itu dalam memuaskan nasabah terdapat prinsip yang harus dipertimbangkan perusahaan adalah memilih lokasi suatu bisnis.

Kesuksesan PT. Bank Rakyat Indonesia Simpang Enam Rantauprapat dalammewujudkan kepuasan nasabah dan loyalitas nasabah tidak terlepas dari faktor-faktor yang berhubungan dengan kepuasan dan loyalitas itu sendiri. Kepuasan dan loyalitas nasabah harus diperhatikan dan dipertahankan bagaimanapun kondisinya. Namun, perusahaan perbankan perlu menyadari bahwa ketika tujuan sudah tercapai biasanya intensitas dan konsistensi pelayanan terganggu hingga menjadi dasar penyebab kepuasan menurun dan nasabah komplain terkait produk dan pelayanan atribut perbankan yang begitu kompleks.

Hal-hal yang mendukung permasalahan pada penelitian ini antara lain adanya gangguan teknis pada jaringan sehingga menyebabkan proses pelayanan dan transaksi menjadi lambat yang membuat nasabah kecewa, komplain mengenai gangguan mesin ATM (Automatic Teller Machine), dan pengaduan nasabah mengenai cara kerja petugas yang tidak simpatik terhadap nasabah yang memiliki permasalahan sederhana.

Semua uraian permasalahan di atas menjadi catatan penting bagi PT. Bank Rakyat Indonesia Simpang Enam Rantauprapat sebagai tolak ukur tingkat kepuasan dan loyalitas nasabah dalam memberikan gambaran tentang kinerja perusahaan berdasarkan perspektif nasabah seperti citra yang melekat pada perusahaan dan apakah citra itu baik ataupun buruk, lokasi perusahaan saat ini, jenis produk, tingkat kecepatan pelayanan yang diberikan bank, dan faktor teknologi yang mendukung operasionalisasi perusahaan serta dampaknya pada persepsi nasabah dimasa mendatang.

Berdasarkan penjelasan latar belakang, penelitian ini bertujuan : Untuk mengetahui pengaruh langsung pelayanan terhadap kepuasan nasabah. Untuk mengetahui pengaruh langsung produk terhadap kepuasan nasabah. Untuk mengetahui pengaruh langsung citra terhadap kepuasan nasabah. Untuk mengetahui pengaruh langsung teknologi terhadap kepuasan nasabah. Untuk mengetahui pengaruh langsung lokasi terhadap kepuasan nasabah. Untuk mengetahui pengaruh langsung kepuasan terhadap loyalitas nasabah

\section{Kajian Pustaka Pelayanan}

Pelayanan adalah sistem manajemen strategik dan integratif yang melibatkan semua manajer dan petugas, serta menggunakan metode-metode kualitatif dan kuantitatif untuk memperbaiki secara berkesinambungan proses-proses organisasi, agar dapat memenuhi dan 
melebihi kebutuhan, keinginan, dan harapan pelanggan". Hal tersebut sejalan dengan yang dikemukakan Pasolog (2007) bahwa pelayanan yang baik adalah kemampuan seseorang dalam memberikan pelayanan yang dapat memberikan kepuasan kepada pelanggan dengan standar yang ditentukan. Sehingga kualitas pelayanan mengarahkan pada tingkat kesempurnaan yang diharapkan dan pengendalian atas kesempurnaan tersebut untuk memenuhi keinginanpelanggannya.

Menurut Tjiptono (2004), bahwa pelayanan yang berhasil guna dalam suatu organisasi adalah bahwa pelayanan yang diberikan oleh anggota organisasi tersebut dapat memberikan kepuasan kepada pelanggannya. Sebagai tolak ukur adalah tidak adanya atau kurangnya keluhan dari pelanggan. Konsep pelayanan dapat dipahami melalui perilaku pelanggan yaitu perilaku yang dimainkan oleh pelanggan dalam mencari, membeli, menggunakan, dan mengevaluasi suatu produk pelayanan yang diharapkan mampu memenuhi kebutuhannya. Keputusan-keputusan pelanggan untuk mengkonsumsi atau tidak mengkonsumsi suatu barang/ jasa dipengaruhi berbagai faktor, antara lain persepsinya terhadap kualitas pelayanan.

Produk

Produk merupakan titik pusat dari kegiatan pemasaran karena produk merupakan hasil dari suatu perusahaan yang dapat ditawarkan ke pasar untuk di konsumsi dan merupakan alat dari suatu perusahaan untuk mencapai tujuan dari perusahaannya. Suatu produk harus memiliki keunggulan dari produk-produk yang lain baik dari segi kualitas, desain, bentuk, ukuran, kemasan, pelayanan, garansi, dan rasa agar dapat menarik minat pelanggan untuk mencoba dan membeli produk tersebut.Menurut Saladin (2003), produk merupakan segala sesuatu yang dapat ditawarkan kesuatu pasar untuk diperhatikan, dimiliki, dipakai, atau dikonsumsi sehingga dapat memuaskan keinginan dan kebutuhan pelanggan.

Menurut Kotler dan Keller (2008), produk adalah elemen kunci dalam keseluruhan penawaran pasar. Selain itu produk dapat pula didefinisikan sebagai persepsi pelanggan yang dijabarkan oleh produsen melalui hasil produksinya. Secara konseptual produk adalah pemahaman subjektif dari produsen atas sesuatu yang bisa ditawarkan sebagai usaha untuk mencapai tujuan organisasi melalui pemenuhan kebutuhan dan kegiatan pelanggan, sesuai dengan kompetensi dan kapasitas organisasi serta daya beli pasar.

Dari definisi diatas dapat disimpulkan bahwa produk merupakan segala sesuatu yang dapat ditawarkan kepada pelanggan yang diciptakan oleh perusahaan untuk digunakan dan dikonsumsi sehingga dapat memuaskan keinginan dan kebutuhan pelanggan baik bersifat berwujud maupun tidak berwujud.

\section{Citra}

Istilah citra perusahaan berkaitan erat dengan lingkup kegiatan pemasaran, karena salah satu tujuan pemasaran adalah menciptakan citra (image) perusahaan di mata publik. Menurut Kotler (2002), citra adalah kumpulan kepercayaan, citra adalah kumpulan kepercayaan, buah pikir atau gagasan dan kesan yang dimiliki seseorang terhadap suatu objek. Penelitian Aaker dan Keller (1990) dalam penelitiannya menguji pengaruh citra perusahaan terhadap kepuasan pelanggan, dan dimana hasil penelitiannya menunjukkan bahwa citra yang baik dari perusahaan mampu meningkatkan kepuasan dari pelanggan akan produk perusahaan. Fornel (1992) menyatakan bahwa citra perusahaan yang melekat pada benak pelanggan akan menambah kepuasan pelanggan yang mengakibatkan loyalitas terhadap produk perusahaan. Dimana dalam meningkatkan penjualan, kesadaran dan citra perusahaan jasa mempengaruhi 
keputusan pelanggan untuk membeli. Pada konteks ini citra perusahaan yang baik yang ditampilkan perusahaan kepada pelanggan melalui citra perusahaan mampu memberikan kepercayaan yang tinggi dari pelanggan sehingga timbul rasa puas daripelanggan.

Teknologi

Secara etimologi, kata teknologi berasal dari dua kata yaitu techno yang berarti seni, dan logia (logos) yang berarti ilmu, teori. Teknologi merupakan aplikasi dan engineering untuk mengembangkan mesin dan prosedur agar memperluas dan memperbaiki kondisi manusia atau paling tidak memperbaiki efisiensi manusia pada berbagai aspek. Teknologi merupakan semua manifestasi dalam arti materil yang lahir dari daya cipta manusis untuk membuat segala sesuatu yang bermanfaat guna mempertahankan kehidupannya.

Dalam mengatasi tekanan bisnis yang ada solusi yang bisa digunakan dengan pemanfaatan teknologi informasi. Menurut O'brien (2003) menambahkan bahwa teknologi informasi mencakup konsep-konsep utama, pengembangan-pengembangan dan isu-isu manajemen seputar teknologi informasi.

\section{Lokasi}

Lokasi menurut Swastha dan Irawan (2003) adalah letak atau perusahaan pada daerahstrategis sehingga dapat memaksimumkan laba. Sedangkan menurut Lupiyoadi (2001), lokasi adalah tempat dimana perusahaan harus bermarkas melakukan operasi. Dalam hal ini ada tiga jenis interaksi yang mempengaruhi lokasi yaitu pelanggan mendatangi perusahaan, apabila keadaannya seperti maka lokasi menjadi sangatpenting.

Perusahaan sebaiknya memilih tempat dekat dengan nasabah sehingga mudah dijangkau dengan kata lain harus strategis, pemberi jasa mendatangi nasabah, dalam hal ini lokasi tidak terlalu penting tetapi yang harus diperhatikan adalah penyampaian jasa harus tetap berkualitas dan pemberi jasa dan nasabah tidak bertemu langsung, berarti service provider dan pelanggan berinteraksi melalui sarana tertentu seperti telepon, komputer dan surat.

Lokasi berpengaruh terhadap dimensi-dimensi strategik, seperti fleksibilitas, competitive positioning, manajemen permintaan, dan focus strategic. Fleksibilitas sebuah lokasi merupakan ukuran sejauh mana sebuah jasa mampu bereaksi terhadap situasi perekonomian yang berubah. Keputusan pemilihan lokasi berkaitan dengan komitmen jangka panjang terhadap aspek-aspek yang sifatnya kapital intensif, karena itu penyedia jasa harus mempertimbangkan, menyeleksi dan memilih lokasi yang responsif terhadap kemungkinan perubahan ekonomi, demografis, budaya, persaingan dan peraturan di masa mendatang.

Suatu lokasi disebut strategis bila berada dipusat kota, kepadatan populasi. kemudahan mencapainya menyangkut kemudahan transportasi umum, kelancaran lalu lintas dan arahnya tidak membingungkan nasabah. Sejalan dengan semakin menjamurnya bisnis atau usaha yang menawarkan produk atau jasa yang sejenis, perbedaan yang sangat tipis sekalipun pada lokasi dapat berdampak kuat pada pangsa pasar dan kemampulabaan sebuah usaha. Disamping itu, keputusan pemilihan suatu lokasi juga mencerminkan komitmen jangka panjang perusahaan dalam hal keuangan, karena merubah lokasi yang buruk kadang kala sulit dilakukan dan sangat mahal (Nugroho dan Paramita, 2009).

\section{Kepuasan Nasabah}

Konsep kepuasan nasabah yang sedang berkembang belakangan ini adalah konsep pemasaran yang berorientasi kepada nasabah. Perusahaan tidak hanya menjual produk atau jasa yang ditawarkan namun perusahaan harus berfokus kepada nasabah sehingga kegiatan pemasaran yang diberlakukan selalu berdasarkan pada kebutuhan nasabah. Selain itu, perusahaan juga perlu memberikan kesempatan seluas-luasnya kepada para nasabahnya untuk menyampaikan pendapat, saran serta kritik. Memperhatikan suara nasabah merupakan hal 
yang bermanfaat bagi perusahaan untuk selalu memperhatikan kebutuhan dan keinginan mereka serta berusaha memenuhi apa yang menjadi harapannasabah. Kepuasan nasabah menurut Gerson (2002), adalah persepsi nasabah bahwa harapannya telah terpenuhi atau terlampaui. Jika seseorang membeli suatu produk atau jasa yang ditawarkan biasanya memiliki ekspektasi atau harapan terhadap produk atau jasa yang dibelinya tersebut. Jika kualitas mutu dan pelayanan produk yang diterimanya melebihi yang diharapkan maka akan timbul kepuasan tersendiri terhadap nasabah tersebut. Menurut Irawan (2002), nasabah merupakan hal yang paling penting dalam suatu perusahaan dan bisa dikatakan bahwa hidup dan matinya suatu perusahaan bergantung pada nasabah. Sebab itu, banyak perusahaan saling bersaing untuk dapat memberikan pelayanan paling terbaik kepada nasabahnya sehingga nasabah enggan untuk beralih atau pindah ke penyedia jasa yang lain. Menurut Aritonang (2005) adalah sebagai hasil penilaian pelanggan terhadap apa yang diharapkannya dengan membeli dan mengkonsumsi suatu produk. Harapan itu lantas dibandingkan dengan persepsinya terhadap kinerja yang diterimanya dengan persepsinya terhadap kinerja yang diterimanya dengan mengkonsumsi produk itu.

Loyalitas Nasabah

Secara harfiah loyal berarti setia, atau loyalitas dapat diartikan sebagai suatu kesetiaan. Kesetiaan ini timbil tanpa adanya paksaan, tetapi timbul dari kesadaran sendiri pada masa lalu. Usaha yang dilakukan untuk menciptakan kepuasaan pelanggan lebih cenderung mempengaruhi sikap pelanggan. Sedangkan konsep loyalitas pelanggan lebih menekankan kepada perilaku pembeliannya. Istilah loyalitas sering kali diperdengarkan oleh pakar pemasaran maupun praktisi bisnis, loyalitas merupakan konsep yang tampak mudah dibicarakan dalam konteks sehari-hari, tetap menjadi lebih sulit ketika dianalisis maknanya. Loyalitas pelanggan merupakan salah satu tujuan inti yang diupayakan dalam pemasaran modern. Hal ini dikarenakan dengan loyalitas diharapkan perusahaan akan mendapatkan keuntungan jangka panjang atas hubungan mutualisme yang terjalin dalam kurun waktutertentu. Griffin (dalam Dharmayanti, 2006) berpendapat bahwa pelanggan yang loyal adalah pelanggan yang sangat puas dengan produk atau jasa tertentu sehingga mempunyai antusiasme untuk memperkenalkannya kepada siapapun yang dikenal. Dari berbagai uraian tersebut dapat disimpulkan bahwa definisi loyalitas dari pakar yang disebutkan diatas berdasarkan pada dua pendekatan, yaitu sikap dan perilaku. Dalam pendekatan perilaku, perlu dibedakan antara loyalitas dan perilaku beli ulang. Perilaku beli ulang dapat diartikan sebagai perilaku pelanggan yang hanya membeli suatu produk secara berulang-ulang tanpa menyertakan aspek perasaan dan pemilikannya di dalamnya. Sebaliknya loyalitas mengandung aspek kesukaan pelanggan pada suatu produk, ini berarti aspek sikap tercakup didalamnya.

Berdasarkan uraian tersebut, maka hipotesis yang diajukan sebagai berikut :

Hipotesis 1 : Pelayanan berpengaruh langsung terhadap kepuasan nasabah.

Hipotesis 2 : Produk berpengaruh langsung terhadap kepuasan nasabah

Hipotesis 3 : Citra berpengaruh langsung terhadap kepuasan nasabah.

Hipotesis 4 : Teknologi berpengaruh langsung terhadap kepuasan nasabah.

Hipotesis 5 : Lokasi berbengaruh langsung terhadap kepuasannasabah.

Hipotesis 6 : Kepuasan berpengaruh langsung terhadap loyalitas nasabah.

\section{Metode Penelitian}

Pada penelitian ini menggunakan metode deskriptif dan analisis kuantitatif. Selanjutnya data yang digunakan adalah data primer dan data sekunder. Penelitian ini diawali dengan 
mengumpulkan data sekunder yaitu dengan melakukan studi literatur yang mencakup kajian teori, penelitian sebelumnya dan model yang berkaitan dengan masalah yang diperoleh dari perpustakaan dan internet. Kemudian dilanjutkan dengan pengumpulan data primer melalui kuesioner dari 100 (seratus) responden yang merupakan nasabah Bank Rakyat Indonesia Simpang Enam Rantauprapat. Penentuan populasi dalam penelitian ini jumlah nasabah yang menabung pada Bank Rakyat Indonesia Simpang Enam Rantauprapat tahun 2015 sebanyak 13.534 orang. Untuk menentukan sampel yang tepat dan sesuai dengan ketentuan yang berlaku dalam penulisan ilmiah, penulis dalam menentukan jumlah sampel menggunakan rumus Slovin, berikut disajikan rumus dan hasil perhitungan yang dilakukan :

$$
n=\frac{N}{1+N \cdot e^{2}} \frac{13534}{1+13534 \cdot(0,1)^{2}}=99,3=100
$$

Keterangan :

$\mathrm{N}=$ Jumlahsampel $\mathrm{n}$

$=\quad$ Jumlahpopulasi

$\mathrm{e}=$ Batas ketelitian yangdiinginkan

Teknik pengambilan sampel yang digunakan dalam penelitian ini adalah metode purposive sampling yaitu penarikan sampel dengan pertimbangan tertentu, pertimbangan tersebut didasarkan pada kepentingan atau tujuan penelitian (Sugiyono, 2014). Dalam penelitian ini ada dua teknik yang digunakan dalam pengumpulan data yaitu riset lapangan dan riset kepustakaan.

\section{Hasil Analisis}

Uji terhadap model menunjukkan bahwa model ini sesuai dengan data atau fit dengan data yang digunakan dalam studi ini. Hasil pengujian model dapat dilihat pada Tabel 1 dibawah ini.

Tabel 1. Goodness of Fit Index

$\begin{array}{cccc}\text { Kriteria } & \text { Hasil } & \begin{array}{c}\text { Cut of } \\ \text { Value }\end{array} & \text { Keterangan } \\ \text { Chii-square } & 14,775 & \text { Kecil } & \text { Baik } \\ \text { Probability } & 0,11 & 0,05 & \text { Baik } \\ \text { GF } & 0,962 & 0,90 & \text { Baik } \\ \text { AGFI } & 0,787 & 0,90 & \text { Marginal } \\ \text { NFI } & 0,808 & 0,90 & \text { Marginal } \\ \text { RMSEA } & 0,141 & 0,08 & \text { Baik }\end{array}$

Sumber : Data Diola, 2016. 


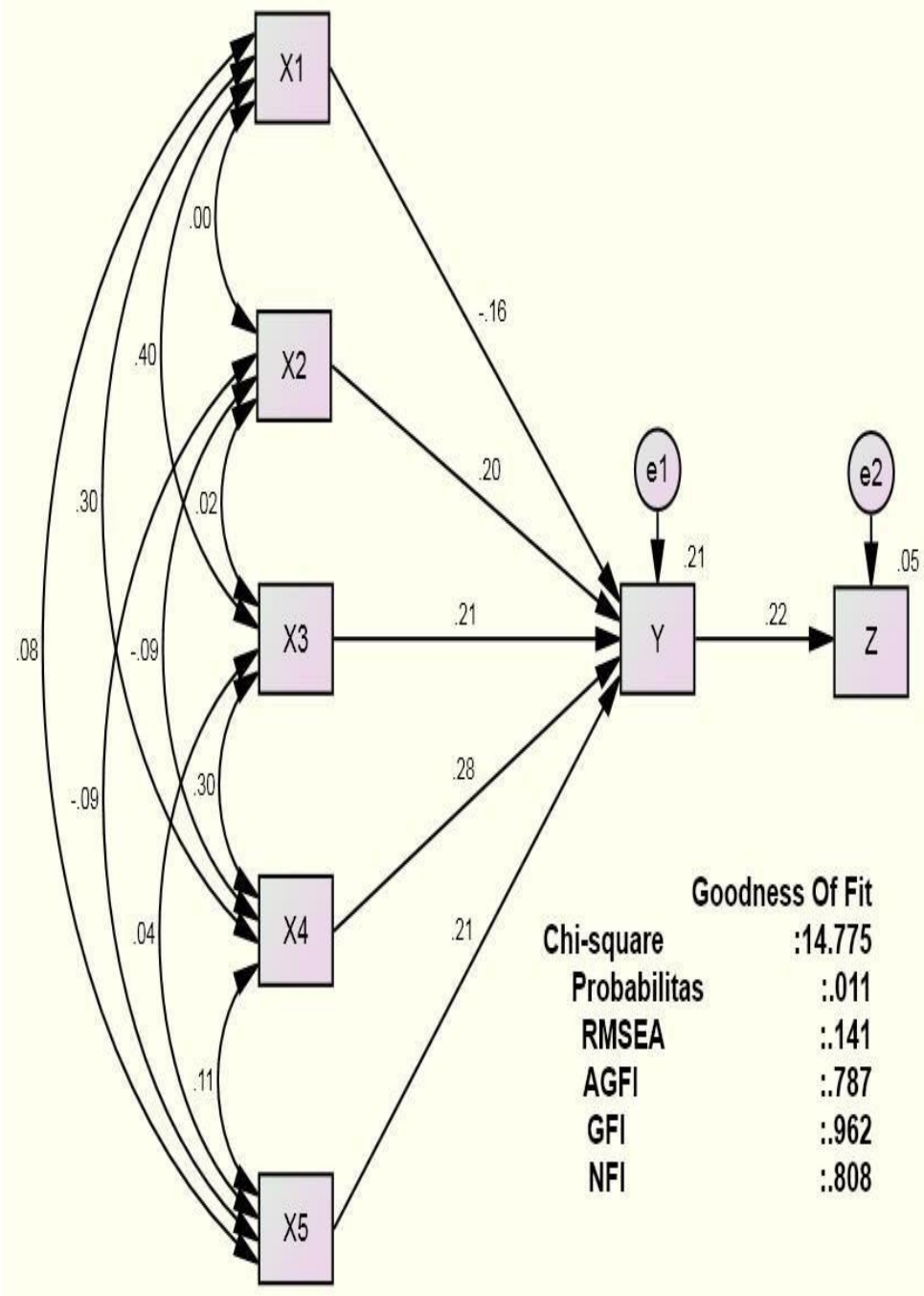

Gambar 1. Hasil Analisis Jalur Tabel 2. Hasil Pengujian Hipotesis

\begin{tabular}{|l|llll|}
\hline \multicolumn{1}{|c|}{ Jalur } & Estimate & SE. & C.R. & P \\
\hline Kepuasan <.. Pelayanan & -.142 & .089 & -1.591 & .112 \\
Kepuasan <.. Produk & .185 & .083 & 2.232 & .026 \\
Kepuasan <-. Citra & .229 & .111 & 2.058 & .040 \\
Kepuasan <-. Teknologi & .232 & .080 & 2.904 & .004 \\
Kepuasan <-. Lokasi & .200 & .086 & 2.321 & .020 \\
Loyalitas <-. Kepuasan & .171 & .075 & 2.289 & .022 \\
\hline
\end{tabular}

Pengujian hipotesis digunakan analisis jalur (path analysis) dengan hasil seperti dalam Gambar 1. Sedangkan hasil pengujian hipotesis dan estimasi dalam Tabel 2, yang hanya memberikan hasil lima hipotesis yangsignifikan. 
1. Pengujian hipotesis 1 memiliki nilai signifikansi ( $p$ value) sebesar 0,112 untuk variabel pelayanan dengan arah koefisien negatif sebesar -0,142 hasil yang tidak signifikan sehingga menunjukkan bahwa pelayanan tidak berpengaruh langsung terhadap kepuasan.

2. Pengujian hipotesis 2 memiliki nilai signifikansi ( $p$ value) sebesar 0,026 untuk variabel produk dengan arah koefisien positif sebesar 0,185 hasil yang signifikan sehingga menunjukkan bahwa produk berpengaruh langsung terhadap kepuasan.

3. Pengujian hipotesis 3 memiliki nilai signifikansi ( $p$ value) sebesar 0,040 untuk variabel citra dengan arah koefisien positif sebesar 0,229 hasil yang signifikan sehingga menunjukkan bahwa citra berpengaruh langsung terhadap kepuasan.

4. Pengujian hipotesis 4 memiliki nilai signifikansi ( $p$ value) sebesar 0,004 untuk variabel teknologi dengan arah koefisien positif sebesar 0,232 hasil yang signifikan sehingga menunjukkan bahwa teknologi berpengaruh langsung terhadap kepuasan.

5. Pengujian hipotesis 5 memiliki nilai signifikansi ( $p$ value) sebesar 0,020 untuk variabel lokasi untuk dengan arah koefisien positif sebesar 0,200 hasil yang signifikan sehingga menunjukkan bahwa lokasi berpengaruh langsung terhadap kepuasan.

6. Pengujian hipotesis 6 memiliki nilai signifikansi ( $p$ value) sebesar 0,022 untuk variabel kepuasan untuk dengan arah koefisien positif sebesar 0,171 hasil yang signifikan sehingga menunjukkan bahwa kepuasan berpengaruh langsung terhadap loyalitas

\section{Penutup} berikut:

Berdasarkan hasil analisis, kesimpulan penelitian ini dapat dikemukakan sebagai

1. Pengujian hipotesis pelayanan tidak berpengaruh langsung terhadapkepuasan.

2. Pengujian hipotesis produk berpengaruh langsung terhadapkepuasan.

3. Pengujian hipotesis citra berpengaruh langsung terhadapkepuasan.

4. Pengujian hipotesis teknologi berpengaruh langsung terhadapkepuasan

5. Pengujian hipotesis lokasi berpengaruh langsung terhadapkepuasan.

6. Pengujian hipotesis kepuasan berpengaruh langsung terhadap loyalitas.

\section{Daftar Pustaka}

Aaker, David A. dan Keller L. Kevin. 1990. Consumer Evalutions of Brand Extensions. Journal of Marketing, 54 (1), 27-41.

Aritonang, Lerbin R. 2005. Kepuasan Pelanggan :Pengukuran dan Penganalisaan dengan SPSS. Jakarta : PT. Gramedia Pustaka Utama.

Dharmayanti, Diah. 2006. Analisa Sensitivitas Respon Konsumen Terhadap Ekstensifikasi Merek (Brand Extension) pada Margarine Merek Filma di Surabaya. Jurnal Manajemen Pemasaran Volume 1 Nomor 2 Oktober 2006.

Fornell, C.1992. A National Customer Barometer: The Swedish Experience", Journal of Marketing, Vol. 56, January

Gerson, Richard F. 2002. Mengukur Kepuasan Pelanggan. Cetakan kedua, Jakarta: PPM.

Kotler, Philip. 2002. Manajemen Pemasaran, Analisa Perencanaan, Implementasi dan Control, Edisi Kesembilan, Jilid 1 dan jilid 2, Jakarta, Prehalindo, alih bahasa oleh Hendra Teguh S.E.,A.K., dan Ronny A. Rusli.S.E. 
Kotler, Philip dan Keller, Kevin. L. 2008. Manajemen Pemasaran Jilid 1. Edisi 12. Alih Bahasa Benyamin Molan. Jakarta : Indeks.

Noor, Akhmad Syafrudin. 2011. Faktor-Faktor Yang Mempengaruhi Kepuasan Nasabah Pada PT Bank Rakyat Indonesia Cabang Pangkalan Bun. Fakultas Hukum Universitas Antakusuma (UNTAMA) Pangkalan Bun. Jurnal Ilmu-ilmu Sosial. Socioscientia.

Nugroho, Marno dan Paramita, Ratih. 2009. “Analisis Pengaruh Lokasi, Keanekaragaman Barang Terhadap Keputusan Berbelanja dan Loyalitas Konsumen di Carrefour Semarang", Jurnal Ekonomi dan Bisnis, Januari, Vol.10, No. 1.

O’Brien, James. 2003. Introduction to Information System Essential for E-Business Enterprise Eleventh Edition. New York : McGraw-Hill.

Pasolog, Harbani.2007. Teori Administrasi Publik. Bandung: Alfabeta.

Saladin, Djaslim. 2003, Manajemen Pemasaran, Bandung: Linda Karya.

Swastha, Basu dan Irawan. 2003. Manajemen Pemasaran Modern, Edisi Kedua Cetakan Ke Sebelas. Yogyakarta : Liberty Offset.

Tjiptono. Fandy. 2004. Marketing Scales. Yogyakarta: Andi Off Set. 